7. Про ратифікацію Конвенції Ради Європи про запобігання тероризму: Закон України від 31 липня 2006 року № 54-V. Відомості Верховної Ради Украӥни. 2006, N 39, ст. 340.

8. Братель О.Г. Екологічний терроризм як дестабілізуючий фактор національної безпеки України. Териризм і національна безпека України: Матеріали міжнар. конф. Київ : Нац. акад. внутр. справ України, 2002. С. 77-84.

9. Конституція України: Закон від 28.06.1996. № 254к/96-BP. URL : http://zakon5.rada. gov.ua.

10.Про національну безпеку: Закон України від 21.06.2018. № 2469-VIII. Вiдомості Верховної Ради, 2018, № 31, ст. 241.

ПРИХОДЬКО А. А.,

кандидат юридичних наук, адвокат

УДК 342.951:351.82

DOI https://doi.org/10.32842/2078-3736-2019-6-2-9

\title{
КОРУПЦІЙНИЙ ЧИННИК ЯК ДИСТАБІЛІЗАЦІЙНИЙ ЕЛЕМЕНТ НА ШЛЯХУ ДО ЄВРОІНТЕГРАЦІї
}

Стаття присвячена аналізу результативності сформованої антикорупційної політики України та дослідженню реального стану виконання низки вимог Європейського Союзу, висунутих Україні в рамках Угоди про асоціацію між Україною, з однієї сторони, та Європейським Союзом, Свропейським співтовариством 3 атомної енергії і їхніми державами-членами, 3 іншої сторони, де перша взяла на себе зобов'язання з вирішення проблем у досліджуваній сфері. Автором розглянуто корупцію як явище, що перешкоджає становленню України повноцінним членом Європейського Союзу, досліджено статистичну й аналітичну інформацію щодо масштабів корупції в Україні на основі офіційних документів основних міжнародних партнерів України. Автором оцінено сучасний стан запобігання та протидії корупції в Україні як задовільний, обумовлюючи таку позицію відсутністю стратегічного планування, зокрема затвердженої антикорупційної стратегії на 2018-2020 роки. Зазначено, що активізація викорінення системної корупції почалась тільки зараз, наприкінці 2019 року. Незважаючи на те, що Угода про асоціацію між Україною, з однієї сторони, та Свропейським Союзом, Свропейським співтовариством з атомної енергії і їхніми державами-членами, 3 іншої сторони, офіційно набула чинності 1 вересня 2017 року. Загалом, автор дійшов висновку, що вимоги Європейського Союзу до України, висунуті в рамках зазначеної Угоди, у досліджуваній сфері загалом реалізуються, однак якість таких дій є дещо сумнівною. Вбачається, що доки українська спільнота буде пасивно реагувати на корупційні прояви, уповноважені суб'єкти будуть діяти в рамках обмежених спроможностей та в умовах, що не відповідають стандартам європейського законодавства, - чекати позитивних зрушень марно.

Ключові слова: антикорупиійна політика, антикорупиійна стратегія, ВАС, євроінтеграція, СС, корупиійні прояви, корупчія, НАБУ, НАЗК, протидія та запобігання корупиї, публічна адміністрація.

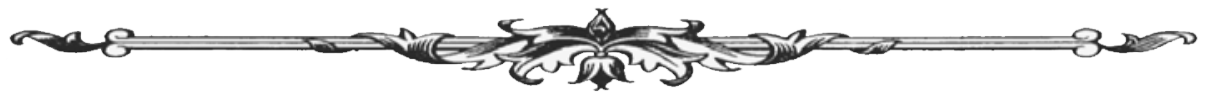


The article is devoted to the analysis of the effectiveness of the anti-corruption policy of Ukraine and the study of the real state of implementation of a number of EU requirements for Ukraine, set in the framework of the Association Agreement between Ukraine, on the one hand, and the European Union, the European Atomic Energy Community and their member states, on the other hand, where the first undertook to solve problems in the studied area. The author considers corruption as a phenomenon that prevents Ukraine from becoming a full member of the EU. Statistical and analytical information on the extent of corruption in Ukraine is studied on the basis of official documents of the main international partners of Ukraine. The author assessed the current state of preventing and combating corruption in Ukraine as satisfactory, stipulating this position as the absence of strategic planning, in particular, an approved anti-corruption strategy for 2018-2020. It is noted that the intensification of the eradication of systemic corruption began only now, at the end of 2019. And this despite the fact that the Association Agreement between Ukraine, on the one hand, and the European Union, the European Atomic Energy Community and their member states, on the other hand, officially entered into force on September 1, 2017. In general, the author came to the conclusion that the EU requirements for Ukraine, set under the framework of this Agreement, are being implemented in the field, but the quality of such actions is somewhat questionable. It seems that while Ukrainian society will passively respond to corruption, authorized entities will act within the framework of limited opportunities and in conditions that do not meet the standards of European legislation - waiting for positive changes is useless.

Key words: anti-corruption policy, anti-corruption strategy, corruption manifestations, corruption, counteraction and prevention of corruption, EU, European integration, National Anti-Corruption Agency, National Anti-Corruption Bureau of Ukraine, public administration, Highest Anti-Corruption Court.

Вступ. Свропейська інтеграція - ключовий пріоритет зовнішньої політики України, який передбачає проведення системних реформ в усіх сферах відповідно до норм і стандартів Європейського Союзу (далі - СС) [1; 2, с. 109].

Однією з основних проблем у досліджуваному аспекті та такою, що має принципове значення для $€ \mathrm{C}, \epsilon$ системна корупція в публічному та приватному секторах в Україні. Це всеохоплююче явище, яке пронизує все суспільство, загрожує національній безпеці, реально протистоїть конституційному і суспільному ладу, є однією із причин зростання в Україні «тіньової» економіки. Вона проникає у владні інституції, залучаючи у свої ряди окремих політичних і громадських діячів. Корупційні прояви вражають усі сфери суспільного життя, призводять до поширення організованої злочинності, створюють соціальне напруження, породжують у населення зневіру у здатність влади здійснити організаційні та практичні заходи щодо подолання системної кризи та відродження України [3, с. 3].

3 огляду на зазначене, актуальність дослідження корупції як однісї з перепон на шляху до становлення України повноцінним членом ЄС не потребує додаткового обгрунтування.

Постановка завдання. Метою статті є аналіз результативності сформованої антикорупційної політики України та реального стану виконання низки вимог ЄС до України, поставлених у рамках Угоди про асоціацію, де остання взяла на себе зобов'язання з вирішення проблем у досліджуваній сфері.

Корупцію як системне явище та гальмівний чинник на євроінтеграційному шляху України досліджували багато вітчизняних та іноземних учених, зокрема: А. Волошенко, М. Глотов, Т. Грек, М. Дем'яненко, С. Невмержицький, О. Онищук, І. Пятак, О. Снігерьов, I. Яцків і багато інших. Однак їхні напрацювання стосувались дотичних і суміжних актів заявленої нами до розгляду проблематики.

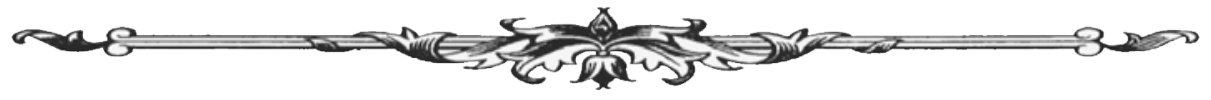


Результати дослідження. На вкрай загрозливі масштаби корупції прямо вказано в нещодавніх офіційних документах основних міжнародних партнерів України. Так, Парламент СС у резолюції від 17 липня 2014 р. (2014/2717 (RSP)) після укладення Угоди про асоціацію з Україною констатував, що в Україні «поширена корупція та наявна колосальна тіньова економіка» (п. 19) [4]. У резолюції від 15 січня 2015 р. (2014/2965 (RSP)) Парламент ЄC зазначив, що антикорупційна стратегія, основною метою якої є нульова терпимість до корупції, украй необхідна Україні, і закликав українську владу вжити заходів щодо «викорінення системної корупції» (п. 13) [5]. У 2017 р. ПАРЄ у своїй резолюції 2145 (2017) продовжує оцінювати корупцію в Україні як «поширену» та висловлює щодо цього особливу занепокоєність (п. 10) [6; 7].

У низці вимог ЄС до України остання в рамках Угоди про асоціацію зобов’язана вирішити проблеми в досліджуваній сфері. Здійснимо спробу розкрити зазначене детальніше.

По-перше, необхідно було оновити національні антикорупційні стратегії та державні програми з її виконання [20].

Нові засади державної антикорупційної політики в Україні передбачені Законом України «Про засади державної антикорупційної політики в Україні (Антикорупційна стратегія) на 2014-2017 рр.». 3 метою їх імплементації, а також належного впровадження нового базового антикорупційного законодавства, зокрема законів України «Про запобігання корупції» та «Про Національне антикорупційне бюро України», Кабінет Міністрів України затвердив Державну програму щодо реалізації засад державної антикорупційної політики в Україні (Антикорупційну стратегію) на 2015-2017 рр. [9].

Метою даного акта було створення системи запобігання корупційним проявам на основі нових засад формування та реалізації антикорупційної політики, періодичний перегляд і забезпечення відповідності актуальним корупційним викликам і загрозам. Серед очікуваних результатів планувалось досягти такого: 1) Національне агентство 3 питань запобігання корупції (далі - НАЗК) утворене та забезпечує ефективне виконання покладених на нього функцій у сфері антикорупційної політики; 2) формування антикорупційної політики здійснюється на основі аналізу якісних даних про корупцію; 3) моніторинг реалізації антикорупційної політики здійснюється системою уповноважених органів (Верховна Рада України, Національна рада $з$ питань антикорупційної політики при Президентові України, Агентство), що забезпечує ефективне і своєчасне коригування антикорупційної політики; 4) громадськість активно залучається до формування, моніторингу та реалізації антикорупційної політики [10].

Однак строк дії даної Антикорупційної стратегії завершується і, згідно з висновками підготовленого НАЗК Аналітичного звіту про ііі виконання, лише дві третини передбачених заходів було виконано [7].

Протягом 2014-2015 рр. ухвалено низку антикорупційних законів, зокрема запроваджено систему електронних закупівель, електронну систему декларування майна, доходів, видатків та зобов'язань фінансового характеру, відкрито державні реєстри щодо інформації про кінцевих бенефіціарних власників. У 2014 р. ухвалено Закон України «Про прокуратуру», у червні 2016 р. - Закон України «Про судоустрій і статус суддів», у грудні 2016 р. Закон України «Про Вищу раду правосуддя». Також утворено низку державних органів, діяльність яких спрямована на подолання корупції, зокрема, окрім згаданого вище НАЗК, це Національне антикорупційне бюро України (далі - НАБУ), Національне агентство України з питань виявлення, розшуку та управління активами, одержаними від корупційних та інших злочинів, Спеціалізовану антикорупційну прокуратуру. Проте не всі зазначені органи своєчасно отримали задовільне матеріальне і кадрове забезпечення та розпочали роботу [9].

Незважаючи на окремі позитивні здобутки, в Україні не повністю завершено формування законодавчої й інституційної основи для розроблення та реалізації антикорупційної політики [9]. Саме тому уряд схвалив проєкт закону України «Про Антикорупційну стратегію на 2018-2020 рр.», розроблений НАЗК із метою визначення комплексу заходів, спрямованих на зменшення рівня корупції в Україні та подальше просування антикорупційних

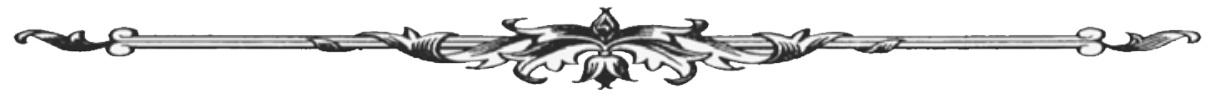


ініціатив у державі [11]. Проте офіційно даний акт не набрав чинності та перебуває у стані корегування.

Наступна вимога - забезпечення функціонування НАЗК та посилення його інституційної спроможності щодо перевірки електронних декларацій осіб, уповноважених на здійснення функцій держави та місцевого самоврядування [8].

НАЗК як центральний орган виконавчої влади зі спеціальним статусом, діяльність якого спрямовується і координується Кабінетом Міністрів України, утворене постановою Кабінету Міністрів України від 18 березня 2015 р. № 118. 3 огляду на правову природу та обсяг компетенції в системі державних органів України, НАЗК відведено роль превентивної антикорупційної інституції, відповідальної за формування та моніторинг реалізації антикорупційної політики в державі, запобігання та врегулювання конфлікту інтересів, здійснення фінансового контролю за майновим станом публічних службовців та моніторингу їхнього способу життя, державне фінансування політичних партій та реалізацію інших, визначених Законом України «Про запобігання корупції» та міжнародними зобов'язаннями України, превентивних антикорупційних механізмів, зокрема забезпечення ведення Єдиного державного реєстру декларацій осіб, уповноважених на виконання функцій держави або місцевого самоврядування, та Єдиного державного реєстру осіб, які вчинили корупційні або пов'язані з корупцією правопорушення [12].

Однією $з$ головних причин критики діяльності НАЗК стали проблеми із системою електронного декларування [13]. НАЗК має вести реєстр декларацій, перевіряти їх, а результати направляти у правоохоронні органи. Фактично, у розпорядженні органу - один із найпотужніших антикорупційних інструментів, створених реформою. Однак два роки НАЗК не могло забезпечити ефективної перевірки декларацій [14].

Українські чиновники повинні були подати свої е-декларації за 2016 р. до 1 квітня 2017 p. Але в березні 2017 р. багато чиновників скаржилися, що не можуть заповнити е-декларації на сайті НАЗК, оскільки Єдиний державний реєстр декларацій працював неналежно [13]. Тобто у 2016 р. $з$ незрозумілих причин там відмовились від автоматичної перевірки. Два наступні роки всі перевірки відбувались у ручному режимі - за 2017-2018 рр. прийнято 615 рішень, або 0,03\% з усіх поданих декларацій [14]. А вже з початку 2019 р. затверджено результати 1474 повних перевірок декларацій, з яких 989 відібрані автоматичною системою [15].

Прес-служба НАЗК запевнює, що Єдиний державний реєстр декларацій осіб, уповноважених на виконання функцій держави або місцевого самоврядування, працює без збоїв, усі подані декларації мають відображатись у Реєстрі. Однак, наприклад, громадськістю зафіксовано факт відсутності цьогорічної декларації глави правління «Укрпошти» (Ігоря Смілянського) [16].

Окрім зазначеного, НАЗК має й інші «слабкі місця», зокрема, на законодавчому рівні не вирішено питання забезпечення йому належного доступу інформації, необхідної для реалізації його повноважень; немає автоматизованого доступу до Спадкового реєстру, Єдиного реєстру довіреностей і Реєстру актів цивільного стану; немає затвердженої антикорупційної стратегії на 2018-2020 рр.; незадовільний стан наповнення державних реєстрів і баз даних, зокрема відсутність у державних реєстрах та базах даних повної інформації, необхідної для автоматизованої перевірки зазначених у деклараціях відомостей; відсутність територіальних органів [15] та ін.

До речі, за результатами опитування 184 респондентів, з яких $80 \%$ є представниками міжнародних компаній, у 2017 р., 36\% опитуваних уважають, що рівень корупції знизився за останній рік (у 2016 р. таких було 47\%). НАБУ, на думку більшості опитаних, є «антикорупційним чемпіоном» у 2017 р. Половина респондентів уважають запуск електронних декларацій найбільшим успіхом в антикорупційній боротьбі за останній рік [12].

Ще однією вимогою для України проголошена необхідність у внесені змін до законодавства щодо права НАБУ знімати інформацію з каналів зв'язку [20].

Постановою Кабінету Міністрів України від 2 березня 2016 р. уряд включив НАБУ до переліку державних органів, яким надано право здійснювати розроблення, виготовлення,

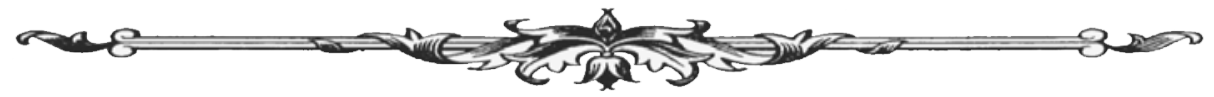


реалізацію та придбання спеціальних технічних засобів для зняття інформації з каналів зв’язку, інших засобів негласного отримання інформації. Постанова ухвалена для забезпечення належного виконання завдань, покладених на НАБУ. Документом вносяться зміни в перелік суб'єктів, які можуть бути державними замовниками розроблення, виготовлення та придбання спеціальних технічних засобів для зняття інформації з каналів зв'язку, інших засобів негласного отримання інформації [17].

Водночас ухвалена постанова Кабміну не вирішує питання щодо можливості НАБУ самостійно знімати інформацію з каналів зв’язку. Виключне право на зняття інформації 3 каналів зв’язку до кінця 2019 р., відповідно до ст. 263 Кримінального процесуального кодексу України, мали Національна поліція й органи безпеки. Бюро отримувало інформацію з каналів зв'язку, користуючись можливостями Служби безпеки України [18]. I тільки 4 жовтня зазначеного року внесено зміни у ст. 263 Кримінального процесуального кодексу, згідно 3 якими НАБУ і Державне бюро розслідувань будуть уповноважені знімати інформацію із транспортних телекомунікаційних мереж, що фактично є правом на прослуховування [19].

Наступна вимога - підвищити рівень кваліфікації вищих посадових осіб, уповноважених на виконання функцій держави або місцевого самоврядування, державних службовців, посадових осіб місцевого самоврядування з питань запобігання та протидії корупції [8].

Здебільшого така діяльність регламентується спеціалізованими професійними програмами підвищення кваліфікації, які розробляються 3 метою формування у працівників органів державної влади й органів місцевого самоврядування навичок запобігання і протидії корупційним правопорушенням [20]. За інформацією, що міститься в Національній доповіді щодо реалізації засад антикорупційної політики у 2018 р., протягом зазначеного року вищезгадані суб'єкти брали участь у навчаннях і тренінгах, ознайомчих заходах та семінарах, організованих як НАЗК, так і фахівцями з питань запобігання та протидії корупції країн Свропи, Азії, а також представниками міжнародних організацій як в Україні, так і за кордоном [21].

Остання нагальна модернізація стосувалась ухвалення законодавства щодо Вищого антикорупційного суду України (далі - ВАС) та забезпечення його повноцінної роботи [8].

Зокрема, 7 червня 2018 р. Верховною Радою України ухвалений Закон України № 2447-VIII «Про Вищий антикорупційний суд», який набрав чинності 14 червня 2018 р., крім пп. 3 п. 2 р. VI «Прикінцеві та перехідні положення» Закону № 2447-VIII (зміни до Кримінального процесуального кодексу України), який набирає чинності із дня початку роботи ВАС. Відповідно до рекомендацій Transparency International Україна на 2018 р., ухвалений Закон загалом відповідає рекомендаціям Венеціанської комісії і передбачає ключову роль міжнародних експертів у доборі суддів, а також для малої приватизації, оренди комунальної нерухомості та вагонів «Укрзалізниці», у продажах яких стали використовувати систему ProZorro [21].

Завдання ВАС - здійснення правосуддя відповідно до визначених законом засад і процедур судочинства 3 метою захисту особи, суспільства та держави від корупційних і пов'язаних із ними злочинів та судового контролю за досудовим розслідуванням цих злочинів, дотриманням прав, свобод та інтересів осіб у кримінальному провадженні, а також вирішення питання про визнання необгрунтованими активів та їх стягнення в дохід держави у випадках, передбачених законом, у порядку цивільного судочинства [22].

Загалом існування ВАС - це іспит для України. Його створення тривало більше трьох років. У Меморандумі про взаєморозуміння між Україною та Свропейським Союзом, ратифікованому Законом № 2613-VIII від 8 листопада 2018 р., підхід до визначення часу початку роботи ВАС був дещо м'якшим, оскільки не передбачав прив'язки до конкретних місяця i року. Завдяки створенню необхідних правових і організаційних умов у період iз 2 серпня 2018 р. до 6 березня 2019 р. відбувся конкурс, результатами якого стало направлення Вищою кваліфікаційною комісією суддів рекомендацій щодо кандидатів на посади суддів до Вищої ради правосуддя. Після цього (18 березня) Вища рада правосуддя внесла Президенту України подання про призначення суддів. 11 квітня 2019 р. Президент України видав укази

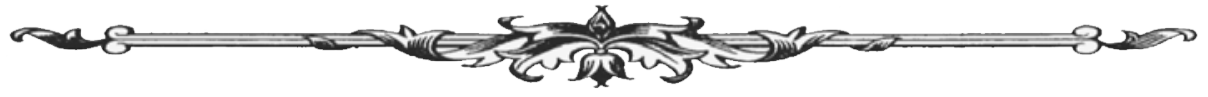


№ 128/2019 і № 129/2019, якими призначив на посади суддів і Апеляційної палати цього суду. Проте саме призначення суддів ще не завершило процес його створення [23].

Збори суддів ВАС 7 травня 2019 р. ухвалили рішення про початок роботи установи 5 вересня [24]. Річ у тому, що станом на дату проведення зборів не було сформованого апарату, працівники якого могли б забезпечити прийняття проваджень для їх розгляду суддями [23].

Водночас деякі рекомендації залишилися невиконаними, зокрема, не підвищилась роль громадськості у процесі перевірки кандидатів на посади суддів [21]. Конкурс для суддів проводився за участю Громадської ради міжнародних експертів замість Громадської ради доброчесності. До складу першої увійшло 6 міжнародних експертів, які мали бездоганну ділову репутацію [25].

Висновки. Усе вищевикладене дає можливість сформулювати висновок, згідно з яким сучасний стан виконання зобов'язань України із запобігання та протидії корупції в державі $€$ задовільним, що обумовлюється насамперед відсутністю стратегічного планування в даній сфері, оскільки відсутність затвердженої антикорупційної стратегії на 2018-2020рр. якнайкраще розкриває зазначене. Активізація викорінення системної корупції почалась тільки зараз, наприкінці 2019 р. Незважаючи на те, що Угода про асоціацію офіційно набула чинності 1 вересня 2017 p.

Вимоги ЄС до України, висунуті в рамках зазначеної Угоди, у досліджуваній сфері загалом реалізуються, однак якість таких дій $є$ дещо сумнівною. Доки українська спільнота буде пасивно реагувати на корупційні прояви, уповноважені суб'єкти будуть діяти в рамках обмежених спроможностей та в умовах, що не відповідають стандартам європейського законодавства, - чекати позитивних зрушень марно.

\section{Список використаних джерел:}

1. Європейська інтеграція. Міжнародна Дипломатична Місія Народної Дипломатії «Європейська Украӥна». URL: euroukraine.com.ua.

2. Волошенко А. Проблема подолання корупції на євроінтеграційному шляху України. Актуальні проблеми економіки. 2016. № 2. С. 108-114.

3. Невмержицький $€$. Корупція як соціально-політичний феномен : автореф. дис. ... докт. політ. наук: 23.00.02. Київ, 2009. 34 с.

4. Corruption Perceptions Index 2014 : Results. Transparency International. 2015. URL: http://www.transparency.org/cpi2014/results/.

5. Резолюция Европейского Парламента от 15 января 2015 г. о ситуации в Украине. Европейский парламент. 2015. URL: http://www.europarl.europa.eu/sides/getDoc. do?type=TA\&reference=P8-TA-2015-0011\&language=EN\&ring $=$ P8-RC-2015-0008 .

6. The functioning of democratic institutions in Ukraine : Resolution 2145 (2017). PACE. URL: http://assembly.coe.int/nw/xml/XRef/Xref-XML2HTML-en.asp?fileid=23453\&lang=en.

7. Пояснювальна записка до проєкту закону України «Про Антикорупційну стратегію на 2018-2020 рр.». Верховна Рада Украӥни. 2019. URL: http://w1.c1.rada.gov.ua/pls/ zweb2/webproc4_1?pf3511=63942.

8. План заходів з виконання Угоди про асоціацію між Україною, з однієї сторони, та Європейським Союзом, Свропейським співтовариством з атомної енергії і їхніми державами-членами, з іншої сторони : постанова Кабінету Міністрів України від 25 жовтня 2017 p. № 1106. Урядовий портал. 2017. URL: https://www.kmu.gov.ua/npas/pro-vikonannya-ugodipro-asociaciyu-mizh-ukrayinoyu-z-odniyeyi-storoni-ta-yevropejskim-soyuzom-yevropejskimspivtovaristvom-z-atomnoyi-energiyi-i-yihnimi-derzhavami-chlenami-z-inshoyi-storoni.

9. Про Антикорупційну стратегію на 2018-2020 pр. : проєкт закону України від 26 квітня 2018 р. № 8324. Платформа LIGA:ZAKON. 2019. URL: http://search.ligazakon.ua/1_ doc2.nsf/link1/JH6F800A.html.

10.Про затвердження Державної програми щодо реалізації засад державної антикорупційної політики в Україні (Антикорупційної стратегії) на 2015-2017рp. : постанова Кабінету Міністрів України від 29 квітня 2015 р. № 265. Урядовий кур’єр. 2015. № 83.

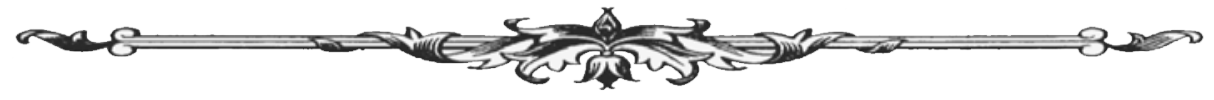


11.Уряд схвалив проєкт закону України «Про Антикорупційну стратегію на 2018-2020 рр.». Урядовий портал. 2018. URL: https://www.kmu.gov.ua/news/uryad-shvalivproekt-zakonu-ukrayini-pro-antikorupcijnu-strategiyu-na-2018-2020-roki.

12.Національна доповідь щодо реалізації засад антикорупційної політики у 2017 р. НАЗК. 2018. URL: https://nazk.gov.ua/wp-content/uploads/2019/06/Natsdopovid-2017.pdf.

13. Дем’яненко М. Ефективність роботи Національного агентства 3 питань запобігання корупції в оцінках політиків і експертів. Украӥна: подї̈, факти, коментарі. 2017. № 8. C. 4-14.

14.НАЗК: 5 проблем, які має вирішити перезапуск провального органу. Реанімаційний пакет реформ. 2019. URL: https://rpr.org.ua/news/nazk-5-problem-yaki-maje-vyrishytyperezapusk-provalnoho-orhanu/.

15. Досягнення, стан справ та плани Агентства на кінець 2019 р. та 2020 р. НАЗК. 2019. URL: https://nazk.gov.ua/uk/novyny/nazk-dosyagnennya-stan-sprav-ta-plany-agentstva-nakinets-2019-ta-2020-rik/.

16.Реєстр декларацій працює без збоїв - НАЗК. Укрінформ. 2019. URL: https://www. ukrinform.ua/rubric-society/2671755-reestr-deklaracij-pracue-bez-zboiv-nazk.html.

17.Про внесення зміни до п. 3 Положення про порядок розроблення, виготовлення, реалізації та придбання спеціальних технічних засобів для зняття інформації з каналів зв'язку, інших засобів негласного отримання інформації. Урядовий портал. 2016. URL: https://www.kmu.gov.ua/npas/248941118.

18.Постанова КМУ не дає повноважень НАБУ самостійно знімати інформацію 3 каналів зв'язку. НАБУ. 2016. URL: https://nabu.gov.ua/novyny/postanova-kmu-ne-dayepovnovazhen-nabu-samostiyno-znimaty-informaciyu-z-kanaliv-zvyazku.

19.Зеленський підписав закон, який дає НАБУ і ДБР автономне право на прослушку. Інтерфакс-Украӥна. 2019. URL: https://ua.interfax.com.ua/news/ general/619034.html.

20.Пояснювальна записка до професійної програми підвищення кваліфікації державних службовців та посадових осіб місцевого самоврядування IV-VII категорій посад 3 питань запобігання і протидії корупції на державній службі та службі в органах місцевого самоврядування. Запорізька обласна державна адміністрація. 2011. URL: http://www. zcppkk.com.ua/download/file/338.

21.Національна доповідь щодо реалізації засад антикорупційної політики у 2018 р. НАЗК. 2019. URL: https://nazk.gov.ua/wp-content/uploads/2019/07/Natsdopovid-2018.pdf.

22. Про Вищий антикорупційний суд : Закон України від 7 червня 2018 р. № 2447-VIII. Голос Украӥни. 2018. № 107.

23. Глотов М. Запуск антикорупційного суду: фінішна пряма, або чому саме 5 вересня обрано днем початку роботи Вищого антикорупційного суду. LexInform. 2019. URL: https://lexinform.com.ua/dumka-eksperta/zapusk-antykoruptsijnogo-sudu-finishna-pryama-abochomu-same-5-veresnya-obrano-dnem-pochatku-roboty-vyshhogo-antykoruptsijnogo-sudu/.

24.Рада ухвалила закон про початок роботи Антикорупційного суду. Укрінформ. 2019. URL: https://www.ukrinform.ua/rubric-polytics/2782481-rada-uhvalila-zakon-pro-pocatokroboti-antikorupcijnogo-sudu.html.

25.Пятак И. ВККС Украины: реформировать нельзя оставлять. Украинская Правда : интернет-издание. 2019. URL: https://www.pravda.com. ua/rus/columns/2019/06/29/7219395/.

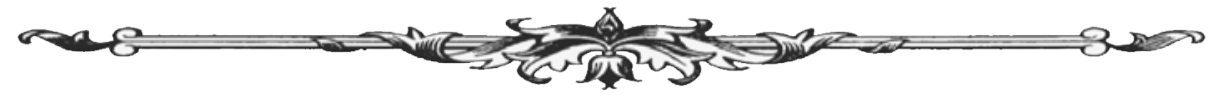

